\title{
Hungarian Defence Forces and Regime Change in 1989-1990: International and Domestic Background
}

\author{
NÉMETH József Lajos ${ }^{1}$
}

\begin{abstract}
The role of the armed forces in the regime change could cover as wide scale of topics as learned in history. In Hungary we experienced a peaceful regime change in 1989-1990. However, many questions were raised about the military role in contemporary events.

It is a fact that the Hungarian Defence Forces were affected by many political changes and challenges in the given time period and it is still a controversial ques- tion why and how it was possible that it played a stabilizing role.

As a first part of a planned paper series, this article seeks to explain some international and domestic events and influencing factors in the period from 1989 to 1990 with the support of the Janos Bolyai Research Scholarship awarded by the Hungarian Academy of Sciences.
\end{abstract}

Keywords: Hungary, armed forces, regime change, role, military, security policy

\section{Introduction}

It is well known and history has proven it many times that the military could play (and usu- ally did) a significant role in regime changes. Its involvement in given political procedures can be described as committing a very brutal series of actions, through to intermediating behaviour, to a very neutral position. Nowadays there are many different transition events, among them the ongoing crisis in Ukraine - starting from the bloody events of the Maidan Square protests in 2014 to the current military operations in Donetsk and Luhansk regions - and these shed new light on the role of armed forces and/or groups. Beyond the daily human losses and collateral damage, the question is raised again: what are the real characteristics of military involvement in political - especially in regime - changes? Of course, due to missing reliable information and proximity of ongoing events we do not yet have healthy historical distance to give adequate answers, but we can describe some influencing factors based on related experience of regional transitions that took place at the end of the Cold War.

Some experts argue that in the cases of the Eastern Block regime changes in 1989-1990 transitions were experienced through:

- regime defeat (Czechoslovak Socialist Republic and German Democratic Republic [GDR]);

- transaction (Romania);

- extrication (Poland and Hungary). [1: 1]

1 e-mail: nemeth.jozsef@uni-nke.hu 


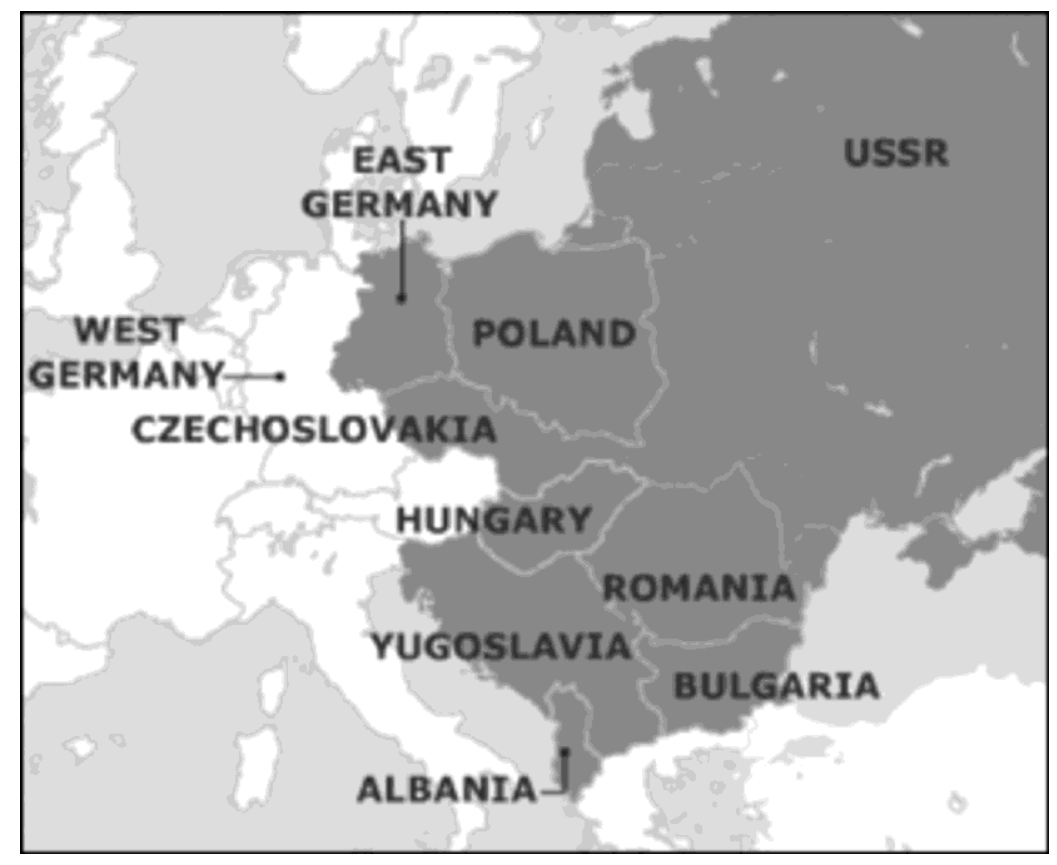

Map 1. Communist regimes in Europe - 1989. [8]

What is common in the above mentioned transition forms is handing power from old ruling elites to a (more or less) new political leadership. What is different is the role of the military, which had direct or indirect influence on the contemporary events.

From political and legal-administrative aspects the regime change in Hungary took al- most a year: the so-called “Opposition Roundtable Talks" (Ellenzéki Kerekasztal) started in March 1989, and the first democratic elections were held in spring 1990. However, we have to emphasize that the changes in politics, in society and in the military as well, started long before and some of them have not even finished yet.

As an initial framework for better understanding the forthcoming paragraphs - as the first part of a series - some important international and domestic events and procedures will be described.

\section{International Framework in the ${ }^{6} 80 \mathrm{~s}$}

The Hungarian historian Fischer Ferenc defines eight different Cold War periods from 1941-1991 in his book entitled "Divided world": [2]

1. Creation and break up of "first antagonist cooperation" (1941-1947);

2. Era of "classical" Cold War (1947-1962);

3. From the era of "classical" Cold War to peaceful coexistence: years of transition - "first cooperative cooperation" (1962-1969);

4. Era of detente - "second antagonist cooperation" (1969-1975);

5. Detente is halted - "second cooperative cooperation" (1975-1979);

6. Years of the "small Cold War" (1979-1985); 
7. Towards final completion: years of transition - "third antagonist cooperation" (1985-1989);

8. Disintegration of the Soviet empire - collapse of the bipolar world (1989-1991). The common features of the above-mentioned periods can be considered in:

- cycles of the arms race, especially in terms of quantitative and qualitative changes in nuclear weapon systems and equipment;

- changes in military doctrines and practice of usage in local (or small) wars;

- changes in the political elite of the opposing parties, which had significant impact in some periods of the Cold War;

- cyclical changes of the world economy, which includes conjunction, stagnation and recession;

- opposition and competition of different international relation schools;

- changes in strategic thinking, especially realizing "ultima ratio" findings by both sides (particularly the possibility of ruthless mutual demolition by nuclear weapons);

- from time to time severe external and internal crises and their "treatment" (the vast majority by military means);

- absolute priority of military dimension precedes political, social, economic and environmental security dimensions and later its radical change.

After analysing the related literature we can identify that an essential and common posi- tion is considered by many experts one of the strongest starting points for the changes con- ducted by Gorbachev's "new thinking". The well-known terms - perestroika and glasnost ${ }^{3}$ - were expressed by him in 1985, when the Warsaw Pact Treaty was extended 10 more years; meanwhile celebrating its $30^{\text {th }}$ anniversary. [3: 291] In the mid-80s the Eastern Bloc countries were still considered a security zone and possible war theatre, especially taking into account such unavoidable influencing factors as Soviet imperial thinking (see the war in Afghanistan) and balancing the new arms race (this was basically the so-called Strategic Defence Initia- tive - SDI) launched (or restarted) by the American president Ronald Reagan in 1983.

Gorbachev expressed the famous "common European house" thoughts in his book enti- tled "Socialism, Peace and Democracy", published in 1987, and later the so-called "Sinatra My Way Doctrine"4 was added to his comprehensive security policy perception. This latter term was a clear message in 1989 for many Eastern European countries; these countries could go their own way, they could decide independently which road to choose. [4]

In general, we can determine that the Soviet imperial thinking significantly changed by the end of the ' $80 \mathrm{~s}$ and gained the characteristics of:

- rejection of nuclear war;

- complex understanding of security;

- devaluation of military force,

- identifying and promoting the mutual nature of security,

- primacy of human values;

- streamlining international relations. [5: 16]

2 Mikhail Gorbachev (1931-), Soviet official, the general secretary of the Communist Party of the Soviet Union from 1985 to 1991 and president of the Soviet Union in 1990-91. [9]

3 Economic and social restructuring and political openness.

4 Kádár János (1912-1989), Premier of Hungary (1956-58, 1961-65) and First Secretary (1956-88) of Hungary's Communist Party. [10] 


\section{Internal Framework in the ${ }^{6} 80 \mathrm{~s}$}

According to the Hungarian historian, Romsics Ignác the Hungarian internal changes can be best described by giving account of how the Kádár regime was losing legitimacy. It means that Hungarian society lost trust in kádárism; by the mid-" 80 s the social acceptance of the on-going system was shaken, and by the end of that decade it shrunk to a minimum. [6]

These changes occurred decisively owing to economic reasons such as:

1. By the early 1980s, the source of a new labour force was depleted, which is a pre- requisite for rapid (and extensive) economic growth. Contributory factors were poor performance indicators as well. (Let us not forget that "competition" was missing or existed just in a very limited way in communist systems.)

2. External economic changes in the " 70 s (in particular, the rise of oil prices and the Hungarian economy energy dependence on the Soviet Union) led to significant price increases. For the maintenance of the "happiest barracks" atmosphere wages (salaries) were increased, which contributed largely to the high budget deficit. To fund this deficit the state took out a significant amount of loans. (Romsics states that between 1970 and 1980, amounts spent on consumption and investment were on a yearly average

2.2\% higher than what the economy produced.) [6]

3. In order to avoid bankruptcy Hungary joined the International Monetary Fund (IMF) and the World Bank in 1982. This step did not only present fiscal emergency relief, but also meant that Hungary became the second communist member state - after Ro- mania - of the Bretton Woods system. From the viewpoint of security policy this step included the acceptance of strict financial measures, which was a "semi-hard tool" of the Western countries. On the other hand, it gave the possibility for Hungarian foreign policy to set up new external relations.

4. The average incomes grew until 1987 and then began to decline, which - of course - affected the mood of society. The political leadership tried to counterbalance this sen- sitive situation by reduced workload and improved personal and political manoeuvre possibilities. (We also have to mention that through the ' $80 \mathrm{~s}$ in Hungary there were no bloody demonstrations such as in Romania or in Poland. Hungarians organized sym- pathy demonstrations to express solidarity and support for those who were killed and beaten in the above mentioned countries.)

5. However, intellectuals, who realized the strategic inoperability of the existing sys- tem, started to be more organized and declared themselves "oppositionist". Romsics claimed that - based on a century long division - this intellectual opposition parted into two main branches: the so-called "urbanists or human rights representatives" and the "national or folk" groups. [6] In addition to these groups, there were certain uni- versity student movements and different platforms, even meetings took place, of which the so-called "meeting in Monor" ${ }^{5}$ stands out, organized in June 1985.

6. In the following years, the oppositionists drew up a variety of programs and initiated movements in different organizational forms (forum, alliance, union, etc.). They set up single and united actions in parallel (for example in the spring of 1988, they estab- lished the Network of Free Initiatives).

5 An illegal meeting held by 45 Hungarian intellectuals at a park in a Hungarian city called "Monor". 
7. The changes markedly altered the internal conditions of the state party (Hungarian Socialist Workers' Party HSWP) and also intensified the struggle between different groups. This resulted not only in the "quasi-fall" of the old Kádár János by May 1988, but the emerging of the "reformists", who had to focus - for the time being - their power on their struggle with the "old ones" (or technocrats).

8. Through 1988 the Central Committee of HSWP accepted decisions, which, on the one hand, made the collapse of social ownership irreversible; on the other hand, they opened the possibility for private property and economic development based on the rules of market and competition. At the same time, the earlier demand became increasingly accepted and claimed that the National Assembly should be the real deci- sion-making branch rather than the state party. Thus the main question became how it would take place? Within the framework of a single or a multi-party system?

9. The question above was decided on 17 February, 1989, since the HSWP took the view that the multi-party system is the only correct answer and solution to the problems. From then on the events gathered pace and finally led to the spring elections in 1990.

\section{General Effects and Raised Issues for Further Research}

The above mentioned events and procedures significantly affected the Hungarian People's

Army (HPA) and resulted in many changes.

Among the external events it is important to emphasize that Hungary as a Warsaw Pact member had to fulfil many operational and procurement expectations set up by the Soviet po- litical and military leaders. However, based on latest research findings, it is essential to point out that the changes in the Soviet Union, in particular the reforms introduced by Mikhail Gorbachev (see "perestroika" and "glasnost") provided much greater leeway for Hungarian political and military leadership to override or "freeze in" some measures. [7]

The participation in different international arms limitation or reduction talks, for example in the Treaty on Conventional Armed Forces in Europe (CFE) gave the opportunity for Bu- dapest to express the Hungarian position on different security and defence policy issues and military doctrines. However, the official speeches given by any Hungarian military leaders were pre-checked by the highest political leadership. It shows that HPA operated under direct party control, which was laid down in different law sources (for example in the Defence Act issued in 1976).

From the mid-' 80 s the military leadership started to look for adequate answers to the evolving economic and social crisis, and as a result there were new measures introduced in

1989-1990, such as:

- transformation of cadre and HR work;

- instead of the official communist address "comrade" ("elvtárs") they reactivated the old term "brother in arms" ("bajtárs");

- elimination of party work and organizations in the armed forces;

- introduction of military (civilian) service without arms;

- changing the name of the "Hungarian People's Army" to "Hungarian Defence Forces";

- establishment of the Hungarian Defence Forces Command. [11]

In addition to the above mentioned fields and events, we need to point out some additional issues. 
Maybe the most important question for many people and oppositionists was how to avoid any possible violent intervention from any side (including police, workers' militia, armed forces, etc.), which could turn back the on-going progress. In other words: what kind of measures and balances were needed to finish peacefully the regime change that started in the mid-'80s? It is a historical fact that the regime change in Hungary happened in a very calm and peaceful manner. However, after a quarter century there is a need to analyse and evaluate the most important influencing factors.

Also we can assume that the relationship between the Hungarian military and political

leadership had some special features, as well as it did towards the ruling Soviet elites.

There were fierce debates (and many rumours) about whether Soviet nuclear weapons were stationed in Hungary or not; nowadays we know that there were.

Another very important field in which further research and analysis is needed is the com- plex tasks related

- to the disarmament of the Workers' Militia;

- to removing the Hungarian iron curtain and opening the border for GDR citizens fleeing through Austria to West Germany;

- to the assistance given to start the withdrawal of the Soviet troops, finished in 1991;

- assistance provided for Romania through the violent events in December 1989;

- to the efforts at restructuring and manpower reduction.

The main characteristics of the relationship between the new political elite elected in spring 1990 and military leadership is still an open issue.

Last, but not least, we need to mention the possible role of the HDF in the "taxi block-ade" that took place in October 1990, which basically resulted in a harsh political debate and judgement of the Constitutional Court.

\section{Conclusions}

The Hungarian regime change happened in a peaceful way in 1989-1990. However, there were many horizontal and vertical challenges. If we would like to understand the real role of the Hungarian Armed Forces - which was able to avoid any violent actions in contemporary events - we need take into consideration the international security policy environment and the domestic events as well.

Additionally, there were some unique events and procedures and for better understanding we can confirm that more research, analyses and evaluation are needed in order to create a comprehensive and authentic view about this crucial period in Hungarian and Eastern Euro- pean history.

\section{References}

[1] SIMON, J.: NATO and Hungary: Problems in Civil-Military Relations. Oxford: Rowman and Littlefield Publishers Inc, 2003.

[2] FISCHER F.: A megosztott világ. A Kelet-Nyugat. Észak-Dél nemzetközi kapcsolatok fö vonásai 1941-1991. (Divided world. Main characteristics of Eastern-Western and Northern- Southern international relations in 1941-1991.) Budapest, Pécs: Dialóg Kiadó, 2001.

[3] SERFÖZÖ L., STERL I.: Védöpajzs. (Shield of Defence.) Budapest: Ifjúsági Lap és Könyvkiadó, 1985. 
[4] "Sinatra Doctrine" at Work in Warsaw Pact, Soviet Says. Los Angeles Times, 25 October, 1989. http://articles.latimes.com/1989-10-25/news/mn-745_1_warsaw-pact, (downloaded: 1402 2015)

[5] SÁRINGER J. (Ed.): Iratok a Magyar Külügyminisztérium történetéhez 1985-1993 I. (Records to the history of Ministry of Foreign Affairs, Hungary.) Budapest: Balassi Kiadó, 2014.

[6] ROMSICS I.: A Kádár-rendszer legitimitásvesztése az 1980-as években. (Legitimacy loss of Kadar regime in '80s.) www.rubicon.hu/magyar/oldalak/a_kadar_rendszer_ legitimitasvesztese_az_1980_as_evekben/(downloaded: 2212 2014) DOI: https://doi.org/10.14753/SE.2013.1757

[7] NÉMETH J. L.: Guided interview with Ferenc Karpati former Minister of Defence in Hungary. s.1., 12 August, 2013. (Handwritten)

[8] BBC: Mapping the fall of communism. BBC News, 30 March 2009. http://news.bbc.co.uk/2/ hi/europe/7972232.stm (downloaded: 1402 2015)

[9] ABDULlaH, M. G. et al. (Eds. ${ }^{6}$ ): Mikhail Gorbachev, President of Union of Soviet Socialist Republics. In. Encyclopcedia Britannica, London: Encyclopædia Britannica (UK) Ltd, 2015.

www.britannica.com/EBchecked/topic/238982/Mikhail-Gorbachev (downloaded: 1402 2015)

[10] ABDULLAH, M. G. et al. (Eds. ${ }^{7}$ ): János Kádár Premier of Hungary. In. Encyclopcedia Britannica, London: Encyclopædia Britannica (UK) Ltd, 2014. www.britannica.com/ EBchecked/topic/309432/Janos-Kadar (downloaded: 1502 2015)

[11] KÁRPÁTI F.: Puskalövés nélkül. (Without Rifle Shooting.) Budapest: Duna International, 2011. 